\title{
Zarys historii amerykańskiej i polskiej młodzieżowej literatury LGBT
}

\begin{abstract}
Abstrakt:
W artykule zaprezentowano genezę młodzieżowej literatury LGBT, a także jej rozwój w Stanach Zjednoczonych od końca lat 60. do czasów współczesnych oraz w Polsce po 1989 roku. Autorka podaje najważniejsze tytuły przynależące do tej odmiany gatunkowej. Reprezentacja osób nieheteroseksualnych oraz transpłciowych w powieściach dla młodych odbiorców zauważalna jest od XX wieku. Z każdym rokiem utworów o takiej tematyce przybywa na amerykańskim rynku wydawniczym, w polskich książkach młodzieżowych inna orientacja niż heteroseksualna czy transpłciowość wciąż są natomiast tematami rzadko poruszanymi. W ostatniej części artykułu autorka podkreśla, dlaczego powinno powstawać coraz więcej takich powieści dla młodego odbiorcy.
\end{abstract}

Słowa kluczowe:

biseksualność, homoseksualność, LGBT, literatura amerykańska, literatura LGBT, literatura młodzieżowa, literatura polska, nieheteronormatywność, transpłciowość

\section{The Outline of the History of American and Polish LGBT Young Adult Literature}

\section{Abstract:}

The article presents the genesis of the LGBT young adult literature and its development in the United States from the late 1960s to the present times and in Poland after 1989. The author lists the most important titles of this genre variant. The representation of non-heterosexual and transgender people in novels for young adults has been noticeable since the $20^{\text {th }}$ century. The number of LGBT books on the American publishing market grows every year, while in Polish young adult books,

* Malwina Niewielska - lic., przygotowuje pracę magisterską na Wydziale Polonistyki na Uniwersytecie Warszawskim dotyczącą literackich obrazów coming outu i trudności, z jakimi muszą się mierzyć nastoletni bohaterowie LGBT w literaturze młodzieżowej. Kontakt: m.niewielska@student.uw.edu.pl. 
non-heterosexual orientation or transgenderism are still rarely mentioned topics. In the final part of the article, the author explains why more LGBT-themed novels for young people should be written.

\section{Key words:}

bisexuality, homosexuality, LGBT, American literature, LGBT literature, young adult literature, Polish literature, non-heteronormativity, transgenderism

\section{Wprowadzenie}

$\mathbf{P}$ o przełomie politycznym w 1989 roku polska literatura otworzyła się na dotąd przemilczane tematy. Mimo to literatura $\mathrm{LGBT}^{1}$ dokonała w Polsce coming outu ${ }^{2}$ dopiero $w$ pierwszych latach XXI wieku³ ${ }^{3}$, po sukcesie powieści Lubiewo Michała Witkowskiego (2004) i na początku trzeciej fali emancypacji

1 Nazywam tak tę odmianę literatury, ponieważ określenia takie jak „gejowska” czy „lesbijska" zawężają pole badań do liter LG, a skrótowiec LGBT (Lesbian, Gay, Bisexual, Transgender) dotyczy nie tylko bohaterów homoseksualnych, lecz także biseksualnych i transpłciowych, którym również poświęcam uwagę w tym artykule. Poza tym, jak zauważa Małgorzata Kita (2016), to określenie „uogólnia problem i jest wolne od konotacji, jakie mogą nieść pozostałe przymiotniki” (s. 116).

2 Więcej o tym i samej literaturze LGBT pisze Kita (2016, s. 113-133), skupia się jednak tylko na publikacjach dla dorosłych czytelników i nie wymienia powieści należących do młodzieżowej literatury LGBT. Piotr Sobolczyk (2015, s. 472-495) jako jedyny teoretyk poświęcił tej literaturze podrozdział w swojej monografii, a o wybranych książkach reprezentujących tę odmianę pisali Dominik Borowski (2015), Alicja Fidowicz (2016), Beata Gromadzka (2018), Anna Kujawska-Kot (2018, 2020), Bogusz Malec (2017), Aleksandra Mochocka (2017), Katarzyna Reszczyńska-Urban (2019), Zofia Ulańska (2018a).

3 „Zaistniała również literatura gejowska i lesbijska, która - inaczej niż ta z poprzedniej dekady - była zauważona, czytana i analizowana, bo kontekst społeczny nadał jej szczególne znaczenie" (Warkocki, 2014, s. 129). Jak wynika z tego cytatu, utwory o tematyce LGBT publikowano w latach 90. (a nawet pojawiały się w poprzednich dekadach - pisarze tacy jak Jarosław Iwaszkiewicz czy Witold Gombrowicz umieszczali w swej twórczości wątki homoerotyczne); mimo że Błażej Warkocki uznaje je za czasy emancypacji gejowskiej i lesbijskiej (s. 123), literatura zawierająca takie wątki przeszła wtedy jednak bez echa, niedostrzeżona przez krytyków (s. 127). Również Kita (2016, s. 117) pisze o tym i przytacza przykład Gorących uczynków Witolda Jabłońskiego (1988). Poza tym Paulina Rogulska (2006) zauważa, że: „W okresie PRL nic, co było odmienne od wyobrażeń i ustaleń narzuconych przez władzę, nie mogło być widoczne (tak niewidoczne miały być między innymi osoby niepełnosprawne fizycznie bądź umysłowo, nie wspominając o takim »odchyle«, za jaki był uważany homoseksualizm)" (s. 10). Opisowi literatury LGBT w czasach PRL-u poświęcił swoją książkę Gejerel. Mniejszości seksualne w PRL-u Krzysztof Tomasik (2012). Witkowski nie był zatem pierwszym autorem poruszającym wątek homoseksualności, ale jego powieść 
homoseksualnej ${ }^{4}$, rozpoczętej w 2003 roku kampanią społeczną Niech nas zobacza (Warkocki, 2014, s. 123, 129). Porównywano ją do zamieszek w Stonewall (Kita, 2016, s. 117), doniosłego wydarzenia w dziejach emancypacji queerowej w USA, gdyż polska społeczność LGBT zaistniała wówczas w przestrzeni publicznej. Dopiero po tym coming oucie ${ }^{5}$ nieheteronormatywne i transpłciowe osoby stały się widoczne również w literackim świecie - dzieło Witkowskiego osiągnęło status bestsellera i znalazło się w obrębie zainteresowania badaczy.

Od tamtej pory postacie LGBT na dobre zagościły w polskich książkach dla dorosłych ${ }^{6} ; \mathrm{w}$ tych przeznaczonych dla młodszych odbiorców nadal jednak pojawiają się rzadko7. Według Katarzyny Reszczyńskiej-Urban (2019, s. 222) jest to spowodowane tym, że homoseksualność musi być określona (tzn. domyślnie każdy jest heteroseksualny i nie trzeba o tym wspominać, osoby nieheteronormatywne muszą natomiast poinformować innych o swojej orientacji lub zostać zidentyfikowane jako takie), co prowadzi do poruszania otwarcie tematu psychoseksualności, którą dorośli nadal uznają za temat tabu wśród dzieci i młodzieży z obawy przed ich seksualizacją i deprawacją. Nie dostrzegają, że akronim LGBT i pojęcie psychoseksualności odnoszą się głównie do

jako pierwsza dotarła do szerokiego grona odbiorców i przetarła szlak innym publikacjom tego typu.

4 Pierwsza, wczesna faza emancypacji, miała miejsce między 1981 a 1990 rokiem, druga w latach 1990-2003 (Warkocki, 2014, s. 123). W trakcie pierwszej oprócz Gorących uczynków powstało m.in. W ptaszarni Grzegorza Musiała (1989). Warto zwrócić uwagę, że polska proza gejowska w tym czasie ukazywała się, ale inaczej było z lesbijską - przełom nastąpił dopiero w 1998 roku, gdy wydano pierwszy polski zbiór opowiadań, których wszystkie główne bohaterki były homoseksualne (Mikołajczak, 2019, s. 2-4).

5 Zgodnie z jedną z definicji coming out składa się nie tylko z pojedynczych aktów ujawnienia się, lecz także ruchów politycznych, dzięki którym budowana jest ogólna widoczność społeczności LGBT (Basiuk, 2010, s. 117).

6 „Sytuacja zmienia się w Polsce drastycznie po opublikowaniu Lubiewa [...] Michała Witkowskiego, które wywołuje prawdziwą lawinę podobnej literatury” (Rejter, 2014, s. 67).

7 Zagadnienie nieheteronormatywności i/lub transpłciowości do tej pory pojawiło się w zaledwie trzech polskich książkach dla dzieci (Jedno oko na Maroko - Kwaśniewski, 2013; Kim jest ślimak Sam? - Pawłowska, Szamałek, 2015; antologia Wszystkie kolory świata Rusinek i in., 2021). Na nasz język przetłumaczono kilka zagranicznych publikacji zawierających wątek LGBT, m.in. amerykańską książkę Z Tango jest nas troje (Parnell, Richardson, 2005/2009), holenderską Król i król (de Haan, Nijland, 2000/2010) czy szwedzką Zlatanka $i$ ukochany wujek (Lindenbaum, 2006/2012). Nie są one jednak przedmiotem niniejszego omówienia, artykuł skupia się bowiem wyłącznie na literackiej reprezentacji nastoletnich osób LGBT, podczas gdy wspomniane pozycje należą raczej do literatury dziecięcej (choć teksty zgromadzone w części wieńczącej zbiór Wszystkie kolory świata mają bardziej młodzieżowy, nastoletni adres czytelniczy; artykuł został napisany przed publikacją tej książki, dlatego zawarte w niej opowiadania nie są tu omawiane). 
ludzi, ich orientacji, tożsamości i związków, nie zaś wyłącznie czynności seksualnych, a w dużej mierze to oni decydują, jakie treści znajdą się w książkach dla młodych czytelników. Trudno jest także starszym pokoleniom - do których należą wydawcy i często też pisarze literatury młodzieżowej - odrzucić przekonanie o tradycyjnym modelu rodziny oraz wielodzietności, na co zwróciła uwagę Zofia Ulańska (2018a, s. 282).

Zgoła inaczej przedstawia się sytuacja w Stanach Zjednoczonych, gdzie już pod koniec lat 60. XX wieku wydano pierwszą na świecie młodzieżową powieść o nieheteroseksualnym bohaterze, Dojdę tam - warto Johna Donovana (1969/1973), i to tam pojawiły się pierwsze książki dla nastolatków o postaciach biseksualnych oraz transpłciowych. W USA z każdą dekadą rośnie liczba takich publikacji, a reprezentacja nastoletnich osób nieheteronormatywnych i transpłciowych staje się coraz bardziej różnorodna ${ }^{8}$, zwłaszcza w ostatnich latach, gdyż skrótowiec LGBT rozszerzył się o kolejne litery, Q, I oraz A, odnoszące się kolejno do ludzi queer (szeroko - nieheteroseksualnych, niecispłciowych, jak również nieidentyfikujących się w całości lub częściowo z tożsamościami wyrażanymi przez pozostałe litery akronimu) lub questioning (niepewnych co do swojej psychoseksualności), interpłciowych (posiadających cechy zarówno żeńskie, jak i męskie) oraz aseksualnych (nieodczuwających pociągu wobec innych osób; Dragan, Iniewicz, 2020, s. 190).

Niniejszy artykuł jest poświęcony zarysowaniu historii młodzieżowej literatury LGBT w Stanach Zjednoczonych i Polsce. Zestawienie to pozwala zobaczyć, jak proza tego rodzaju rozwinęła się na przestrzeni XX i XXI wieku w kraju, w którym powstała, a jaką drogę odbyła w Polsce, gdzie nastąpiła jej późna emancypacja. W dalszej części opracowania wymieniam i opisuję wybrane amerykańskie utwory kierowane do tej grupy odbiorczej i prezentujące postacie LGBT (gdyż byłoby niemożliwe przytoczenie wszystkich w artykule o tej objętości) oraz wszystkie (zgodnie z moją wiedzą) polskie. Na młodzieżową literaturę LGBT składają się w proponowanym tu ujęciu dzieła prozatorskie (poezja i dramat, jako mniej licznie reprezentowane i mniej popularne, nie są tu omawiane), w których główny wątek dotyczy rozterek związanych z psychoseksualnością czy tożsamością płciową bohaterów oraz odnajdywania się protagonistów w społeczeństwie heteronormatywnym oraz cispłciowym; to także

8 Z tego powodu często można się spotkać z określeniem „literatura LGBTQ+”, jak w tytułach opracowań Michaela Carta i Christine A. Jenkins (2006, 2018). Za Kitą (2016) i Ulańską (2018a) zdecydowałam się jednak na używanie krótszego akronimu, m.in. ze względu na to, że w artykule skupiam się wyłącznie na przedstawieniu literackiej reprezentacji osób homoseksualnych, biseksualnych i transpłciowych w okresie adolescencji. 
utwory, w których takie postacie znajdują się na dalszym planie, a ich dążenia do samoakceptacji bądź coming out nie stanowią centrum wydarzeń.

Klasyfikacja tytułów w powyższy sposób nie sprawia trudności, problematyczne natomiast jest jednoznaczne zdefiniowanie literatury młodzieżowej. Po angielsku ten typ twórczości funkcjonuje pod nazwą young adult literature, w skrócie YA, zatem poprawne byłoby tłumaczenie , literatura dla młodych dorosłych" 9 . Young Adult Library Services Association (YALSA), oddział American Library Association (ALA), zakwalifikowała literaturę young adult jako przeznaczoną dla odbiorców między dwunastym a osiemnastym rokiem życia (Peterson, 2018), jednak książki YA okazały się popularne głównie wśród dojrzalszych wiekowo czytelników (Howlett, 2015). Michael Cart (2010, s. 119) zauważa, że termin ten z czasem się rozszerzył i obejmuje coraz starsze osoby, nawet do trzydziestego czwartego roku życia. Z problemem definicji tej literatury mierzą się również polscy badacze. Alicja Baluch $(2005$, s. 65$)$ do twórczości młodzieżowej zalicza te powieści, po które dziecko w wieku około dwunastu lat zaczyna sięgać i czyta je samodzielnie. Według Anny Czabanowskiej-Wróbel (2013, s. 15) literatura młodzieżowa może stanowić określenie konkretnego, lecz często niełatwego do wydzielenia segmentu rynku powieści dla mało wymagającego czytelnika bądź - nobilitująco - należą do niej książki dla młodszych nastolatków.

Chociaż Maciej Skowera twierdzi, że terminy young adult literature i „literatura młodzieżowa" nie są w pełni tożsame (Całek, Olkusz, Korczak, Skowera, 2017, s. 117), ich punktem wspólnym, zgodnie z przytoczonymi wyżej refleksjami, jest osiągnięcie przez czytelnika dwunastego roku życia. Książki dla osób poniżej tej granicy wiekowej można uznać za przynależące do literatury dziecięcej (trudno natomiast ostatecznie wyznaczyć górną granicę literatury young adult czy też młodzieżowej i wydaje się to zadaniem niewykonalnym), co uważam za słuszne, gdyż dzieci zaczynają wówczas dojrzewać psychicznie, biologicznie oraz społecznie (Obuchowska, 1996, s. 9) i zastanawiać się nad tym, czym jest orientacja psychoseksualna (Iniewicz, Mijas, Grabski, 2012, s. 191). To także w tym czasie następuje kulminacyjny moment rozwoju tożsamości płciowej, kształtowanej przez całe życie (Beisert, Witkoś, 2018). Nastoletnie osoby powinny więc mieć możliwość przeczytania powieści, w których bohaterowie rozmyślają nad własną psychoseksualnością, emocjami czy tożsamością genderową oraz wchodzą w relacje z osobami tej samej płci; dlatego tak ważna jest młodzieżowa literatura LGBT.

9 Dla uproszczenia stosuję termin „literatura młodzieżowa” w odniesieniu do tytułów zarówno polskich, jak i amerykańskich. 


\section{Przegląd amerykańskiej młodzieżowej literatury LGBT}

Historia młodzieżowej literatury LGBT zaczyna się w USA od wydania wspomnianej już książki Dojdę tam - warto Donovana. Fabuła dotyczy losów trzynastoletniego Davy’ego, który zaprzyjaźnia się z kolegą z klasy, a następnie dochodzi między nimi do pocałunku (Cart, Jenkins, 2018, s. 9-11). Wydanie tej powieści nie było jednym ze skutków Stonewall, gdyż publikacja nastąpiła w tym samym miesiącu co zamieszki, ale z pewnością oba te wydarzenia były możliwe dzięki temu, że właśnie lata 60 . zapisały się w historii jako początek wyzwolenia osób LGBT (Krzemiński, 2010, s. 43-45). Poza tym wpływ na powstanie książki miała również rewolucja w literaturze dla młodszych odbiorców - pod koniec dekady zaczęto zastępować moralizatorskie utwory dziełami o prawdziwych problemach dojrzewającej młodzieży (Cart, Jenkins, 2006, s. 7); opublikowano wówczas m.in. The Outsiders S. E. Hinton (1967), powieść opowiadającą o rywalizacji gangów złożonych z nastolatków.

Powieść Donovana wzbudziła różne emocje (Cart, Jenkins, 2018, s. xi), ale nie wywołała gwałtownego napływu podobnych publikacji, gdyż następna młodzieżowa książka z postacią LGBT, The Man Without a Face Isabelle Holland $(1972)^{10}$, ukazała się po trzech latach, a kolejna - Trying Hard to Hear You Sandry Scoppettone (1974) - po pięciu (Cart, Jenkins, 2018, s. 226). Niedługo później opublikowano kolejne dwa tytuły - What's This About Pete? Mary W. Sullivan (1976) oraz Ruby Rosy Guy (1976), pierwszej autorki, która w powieści młodzieżowej bohaterką uczyniła czarnoskórą nastoletnią lesbijkę (Waters, 2009). Łącznie w USA w latach 70. ukazało się osiem powieści młodzieżowych o tematyce LGBT, przedstawiały one jednak homoseksualność stereotypowo, prezentowały ją jako przejściową lub łączyły z cierpieniem czy nawet śmiercią bohaterów (Cart, Jenkins, 2006, s. 17, 3738). Często było to wynikiem decyzji wydawców - szczęśliwe zakończenie związku jednopłciowego uważano za niebezpieczne dla nastoletnich czytelników, postrzeganych jako rozchwiani emocjonalnie i niepewni swojej tożsamości (Waters, 2009).

Od następnej dekady powoli zaczęły następować zmiany w wizerunkach postaci nieheteroseksualnych - np. w Annie on My Mind Nancy Garden (1982) uczucie łączące główne bohaterki nie mija wraz z końcem utworu, a ich orientacja jest czymś stałym. W 1985 roku w USA pojawiła się pierwsza zagraniczna książka młodzieżowa LGBT, In the Tent Davida Reesa (1979/1985), oryginalnie

${ }_{10}$ Książka została zekranizowana pod takim samym tytułem (Gibson, 1993), ale bez wątku postaci homoseksualnej (Cart, Jenkins, 2018, s. 226). 
wydana w Wielkiej Brytanii, a pierwszą przetłumaczoną była Damned Strong Love: The True Story of Willi G. and Stefan K. Lutza van Dijka (1991/1995), opowiadająca opartą na faktach historię polskiego nastolatka, który w trakcie II wojny światowej zakochał się w niemieckim żołnierzu ${ }^{11}$.

W latach 1969-1992 w USA ukazało się sześćdziesiąt książek młodzieżowych $z$ postaciami nieheteroseksualnymi, a ich treść nie była raczej postrzegana jako nieodpowiednia dla nastoletnich odbiorców (Abate, Kidd, 2011, s. 148) ${ }^{12}$. Częściej reprezentowani w nich byli geje niż lesbijki - aż czterdzieści cztery powieści opowiadały o postaciach męskich, a tylko szesnaście o żeńskich (s. 150). Tę niewidoczność dziewcząt w utworach powiązać można $z$ tym, że ówcześnie w USA często pomijało się głos kobiet „innych”, tzn. o kolorze skóry innym niż biały, pochodzących z niższych klas społecznych czy właśnie nieheteroseksualnych (Struzik, 2012, s. 14).

Z końcem XX wieku reprezentacja osób LGBT w amerykańskich powieściach młodzieżowych stała się bardziej różnorodna. Pierwszy biseksualny nastolatek pojawił się w "Hello," I lied M. E. Kerrr' (1997), a pierwsza biseksualna nastolatka - w Empress of the World Sary Ryan (2001). W literaturze amerykańskiej odnaleźć można też wiele heteroseksualnych postaci zachowujących się jak biseksualne, ponieważ odkrywają własną psychoseksualność, co sprawia największą trudność w mówieniu o książkowej reprezentacji osób biseksualnych (Cart, Jenkins, 2018, s. 126). Zagadnienie transpłciowości po raz pierwszy w literaturze młodzieżowej poruszyła zaś Francesca Lia Block (1996). W opowiadaniu ze zbioru tej pisarki zatytułowanego Girl Goddess \#9: Nine Stories jedna z matek głównej bohaterki przeszła korektę płci. Młodzież transpłciowa zaś dopiero w pierwszych latach XXI wieku otrzymała reprezentację - w powieści Luna Julie Anne Peters (2004). Historia opowiada o szesnastolatce ukrywającej prawdziwą tożsamość; za dnia udaje chłopca o imieniu Liam, a nocami jest sobą. Za kolejną amerykańską książkę młodzieżową o postaci

11 Polski tytuł powieści to Cholernie mocna miłość. Prawdziwa historia Stefana K. i Williego G. (van Dijk, 1991/2017).

12 W 1993 roku egzemplarze książki Annie on My Mind były palone na schodach szkół w Kansas City, a później usunięte z biblioteki jednej z nich wskutek decyzji dyrektora (NCAC Staff, 1996). W listopadzie 1995 roku zgodnie z wyrokiem sądu powieść przywrócono jednak na półki tej placówki (Cart, Jenkins, 2006, s. xi-xii).

13 Pod tym pseudonimem kryje się Marijane Meaker, autorka pierwszej powieści lesbijskiej Spring Fire, opublikowanej pod pseudonimem Vin Packer (1952). Wydała także powieści młodzieżowe I'll Love You When You're More Like Me (Kerr, 1977), w której przyjaciel głównego bohatera jest gejem, oraz Deliver Us from Evie (Kerr, 1994), opowiadającą o nastoletnich lesbijkach. 
transpłciowej uznać można Parrotfish Ellen Wittlinger (2007). Autorka przedstawia losy Grady’ego, który musi zmierzyć się z nieprzychylnymi opiniami o swojej prawdziwej tożsamości - ze strony nie tylko otoczenia, lecz także najbliższych mu osób.

Młodzieżowa literatura LGBT doczekała się szczegółowych monografii amerykańskich badaczy Michaela Carta i Christine A. Jenkins (2006, 2018); ta ostatnia podzieliła teksty tego typu na trzy kategorie (2018, s. xiv) ${ }^{14}$ : homosexual visibility (HV), gay assimilation (GA), queer consciousness/community (QC). Homosexual visibility odnosi się do obecności bohaterów homoseksualnych $\mathrm{w}$ społeczeństwie ukazanym $\mathrm{w}$ danym tekście, gay assimilation oznacza ich asymilację, trzecią kategorię tłumaczę natomiast jako świadomość/społeczność queerową. Do pierwszej z nich zalicza się większość młodzieżowych powieści $\mathrm{z}$ wątkiem LGBT publikowanych od lat 70. do 80 . XX wieku, a osią ich wydarzeń jest coming out nieheteroseksualnego nastolatka oraz reakcja otoczenia. W utworach zaliczanych do kategorii GA inna niż heteroseksualna orientacja bohaterów jest taką samą cechą jak np. bycie leworęcznym. Książki QC przedstawiają zaś relacje nieheteronormatywnych postaci z ich bliskimi oraz ze społecznością LGBT (s. xiv-xv). Podział Jenkins miał odzwierciedlać to, co działo się w historii osób nieheteronormatywnych po zamieszkach w Stonewall, oraz przedstawiać ewolucję młodzieżowej literatury LGBT (Cart, Jenkins, 2006, s. xix). Ta odmiana gatunkowa została też w XXI wieku doceniona przez krytyków - od 2010 roku Stonewall Book Awards ${ }^{15}$ przyznaje nagrodę dla książki roku w kategorii literatury dla dzieci i młodzieży, będącą pierwszym na świecie i najpopularniejszym wyróżnieniem przyznawaną powieściom młodzieżowym $\mathrm{z}$ bohaterami nieheteronormatywnymi i transpłciowymi (Cart, Jenkins, 2018, s. 265). Choć wydaje się, że wątki LGBT nie powinny wzbudzać oburzenia, skoro krytycy nagradzają zawierającą je prozę, zdarzało się, że w XXI wieku amerykańscy autorzy proszeni byli przez wydawców o usunięcie $\mathrm{z}$ powieści nieheteroseksualnych postaci lub zmianę ich orientacji (Flood, 2011).

Jednym ze znanych współczesnych amerykańskich pisarzy młodzieżowej literatury LGBT jest autor bestsellerowych powieści Raczej szczęśliwy niż nie, Zostawiteś mi tylko przeszłość i Nasz ostatni dzień, Adam Silvera (kolejno 2015/2018, 2017/2018, 2017/2019), którego dzieła ukazały się w Polsce

14 Ten podział powstał na podstawie trzymodelowego systemu opracowanego przez Rudine Sims Bishop, odnoszącego się do bohaterów afroamerykańskich w książkach młodzieżowych (Cart, Jenkins, 2018, s. 272).

15 Amerykańska organizacja nagradzająca literaturę LGBT wydaną w USA. 
nakładem wydawnictwa We need $\mathrm{YA}^{16}$. Silvera napisał również A jeśli to my w duecie z Becky Albertalli (2018/2019), także tworzącą książki o nieheteronormatywnych nastolatkach, takie jak Simon oraz inni homo sapiens, Leah gubi rytm, Odwrotność nieodwzajemniona oraz Love, Creekwood (kolejno Albertalli, 2015/2016, 2017/2019, 2018, 2020). Oboje za debiutanckie powieści otrzymali w 2016 roku nominacje do literackiej nagrody Lambda, przyznawanej książkom z wątkami LGBT (Out.com Editors, 2016). Pierwsze ze wspomnianych wyżej dzieł Albertalli zekranizowano pod tytułem Twój Simon (Berlanti, 2018) - był to pierwszy wyprodukowany przez dużą amerykańską wytwórnię film poprowadzony z perspektywy homoseksualnego nastolatka (Lang, 2018). Na małych ekranach natomiast zadebiutował serial Love, Victor (Berger, Aptaker, 2020- ), osadzony w tym samym świecie co film. Wszystko to świadczy o ogromnym i niesłabnącym po latach zainteresowaniu twórczością Albertalli. Warto wspomnieć, że jej książki mają dobre zakończenia, co też wyjaśnia odniesiony sukces - czytelnicy nie chcą już czytać tylko o nieszczęśliwej miłości osób LGBT. Znanym amerykańskim autorem jest również David Levithan (kolejno 2003, 2013), zawdzięczający sławę powieści Boy Meets Boy oraz książce Two Boys Kissing, za którą w 2014 roku otrzymał nominację do wspomnianej Stonewall Book Award. Jego książki spotkały się z ciepłym przyjęciem w szkołach i bibliotekach (Abate, Kidd, 2011, s. 7), a powieść Will Grayson, Will Grayson, napisana wspólnie przez Levithana i Johna Greena (2010/2015) ${ }^{17}$, znalazła się na trzecim miejscu listy bestsellerów New York Timesa (była pierwszą uwzględnioną w tym notowaniu książką z homoseksualnymi bohaterami, co stanowi duże wyróżnienie; John Green Books, b.d.). Docenili ją także krytycy - w 2011 roku nominowano ją do Stonewall Book Awards. Osoby transpłciowe swoją reprezentację odnaleźć zaś mogą w powieści Felix Ever After. Na zawsze Felix Kacena Callendera (2020/2021), autora nagrodzonego Stonewall Book Award. Książka ta jest opowieścią o chłopcu, który przeszedł już korektę płci, i z powodu tego, kim jest, doświadcza transfobii. Powieść otrzymała nominację w plebiscycie czytelniczym Goodreads Choice Awards 2020 w kategorii Best Young Adult Fiction.

16 To wydawnictwo wydało również inne utwory młodzieżowe o tematyce LGBT, np. Te wiedźmy nie płona i Ten sabat nie upadnie Isabel Sterling (kolejno 2019/2020, 2020/2021), czyli książki opowiadające o homoseksualnej nastoletniej wiedźmie, wspomnianą dalej w powyższym akapicie Leah gubi rytm Becky Albertalli (2017/2019) czy Felix Ever After. Na zawsze Felix Kacena Callendera (2020/2021).

17 Współpraca z Greenem, popularnym autorem heteroseksualnym, zdecydowanie przyczyniła się do zwiększenia widoczności twórczości Levithana. 
W wymienionych powyżej współczesnych utworach wątek LGBT jest tym głównym, ale pojawiają się też powieści, w których nieheteroseksualne i transpłciowe postacie są drugoplanowe i dzięki swojej obecności sprawiają, że nienormatywność w środowisku heteroseksualnym jest czymś zwyczajnym, a nie powodem do drwin czy wykluczenia. Bohaterowie LGBT występują nie tylko w książkach obyczajowych dla młodzieży, lecz także w fantasy oraz science fiction, np. w sześciotomowym cyklu Dary Anioła Cassandy Clare (2007/2009a-2014; pojawiający się tam homoseksualny Alec i biseksualny Magnus doczekali się osobnej trylogii o swoich przygodach, rozpoczynającej się od Czerwonych zwojów magii, 2019/2020, wydanej w Polsce, tak jak np. książki Silvery, przez We need YA) czy w powieściach Nie poddawaj się i Zbłąkany syn autorstwa Rainbow Rowell (kolejno 2015/2016, 2019), jak również w Synu nieskończoności Silvery (2020/2021), jego pierwszej książce należącej całkowicie do gatunku fantasy (do tej pory w jego twórczości pojawiały się jedynie elementy fantastyczne).

\section{Przegląd polskiej młodzieżowej literatury LGBT}

Nieheteroseksualni i transpłciowi nastolatkowie długo pozostawali nieobecni w polskich utworach literackich, a przynajmniej o ich psychoseksualności oraz tożsamości płciowej nie mówiło się wprost, co wykazała Alicja Fidowicz (2016) po odczytaniu w kategoriach queer powieści Nad czarnq woda Haliny Górskiej (1931). Po raz pierwszy o homoseksualności wśród młodzieży pozornie całkowicie heteronormatywnej otwarcie napisała w Kolacji na Titanicu Krystyna Boglar $(1991)^{18}$. Był to jednak wątek poboczny, zredukowany do pamiętnika jednego z bohaterów, który bał się komukolwiek wyznać prawdę o swojej orientacji z obawy przed niezrozumieniem i wykluczeniem z grupy rówieśników. W XX wieku nie ukazała się inna polska książka młodzieżowa z postacią LGBT, ale czytelnicy mogli zapoznać się z historią homoseksualnego piętnastolatka Jima Lundgrena w przetłumaczonej na nasz język powieści Jim w lustrze Inger Edelfeldt (1977/1996), będącej debiutem szwedzkiej pisarki.

18 W żadnym poprzednim artykule, w którym dokonano przeglądu polskiej młodzieżowej literatury LGBT, ten tytuł się nie pojawia. Piotr Sobolczyk (2015) wymienia jedynie dzieła Ciwoniuk (2010) oraz Onichimowskiej (2012). Fidowicz (2016) w swoim zarysie historii owej literatury przytacza artykuł Sobolczyka i uzupełnia spis o inne utwory, jednak ta powieść również nie zostaje wspomniana przez badaczkę. 
Następny po bohaterze Boglar homoseksualny nastolatek w polskiej literaturze młodzieżowej pojawił się dopiero w powieści Musisz to komuś powiedzieć Barbary Ciwoniuk (2010). Podobnie jak w Kolacji na Titanicu nie był on pierwszoplanową postacią i nie powiedział nikomu o swoich rozterkach związanych $\mathrm{z}$ orientacją, tylko zawarł je $\mathrm{w}$ liście napisanym do głównej bohaterki. Za pomocą tych wątków autorki jedynie zasygnalizowały więc obecność nieheteronormatywnej młodzieży. W książce Koniec gry Anna Onichimowska (2012) jako pierwsza polska pisarka skupiła się na rozwoju psychoseksualności nastoletniego bohatera, który za sprawą spotkania rodzinnego po latach przypomina sobie czasy młodości, gdy powoli zaczynał rozumieć, kim tak naprawdę jest. Reszczyńska-Urban (2019, s. 222) zwróciła uwagę na to, że w dziełach Ciwoniuk i Onichimowskiej brakuje opisów uczuć towarzyszących odkrywaniu orientacji homoseksualnej oraz angażującej odbiorców historii miłosnej. Czytelnicy nie znajdą tego również w Kolacji na Titanicu.

Dopiero w trylogii rozpoczynającej się od Fanfika Natalia Osińska (kolejno 2016, 2017, 2019) zawarła nieobecne dotąd w polskiej literaturze młodzieżowej opisy odkrywania tożsamości nieheteronormatywnej i transpłciowej przez nastoletnich bohaterów (Reszczyńska-Urban, 2019, s. 223). Autorka ta przedstawia historie dorastających osób LGBT mieszkających w Poznaniu. W debiutanckiej książce koncentruje się na dążeniach transpłciowego Tośka do bycia prawdziwym sobą. Z perspektywy jego chłopaka Leona opowiedziana jest druga część, Slash. Obaj pojawiają się także we Fluffie, tym razem jako poboczni bohaterowie, gdyż tom wieńczący trylogię poświęcony został opisowi związku Matyldy, koleżanki Tośka, z jej dziewczyną Wiką. Osińska jako jedyna do tej pory polska autorka w swoich powieściach młodzieżowych głównymi bohaterami uczyniła transpłciowego chłopca oraz nieheteroseksualne dziewczęta. Nowatorskie w jej twórczości jest również to, że we Fluffie pojawia się postać nieidentyfikująca się z żadną płcią. Wkład pisarki w rozwój literatury LGBT dla nastoletnich odbiorców docenili zarówno czytelnicy, jak i krytycy oraz badacze. Powstało wiele artykułów omawiających utwory Osińskiej, m.in. Anny Kujawskiej-Kot (2018, 2020), Bogusza Malca (2017), Reszczyńskiej-Urban (2019) czy Ulańskiej (2018a). W 2016 roku Fanfik zdobył wyróżnienie w IX Konkursie Literatury Dziecięcej im. Haliny Skrobiszewskiej, dzięki czemu umieszczono go na Liście Skarbów Muzeum Książki Dziecięcej. Debiut Osińskiej znalazł się także wśród powieści nominowanych do nagrody strony Lubimy Czytać Książka Roku $2016{ }^{19}$ w kategorii literatura młodzieżowa. Trzeci

19 Nominacje przyznaje się na podstawie popularności danego tytułu w serwisie. 
tom, podobnie jak pierwszy, odniósł sukces na tym portalu - otrzymał nominację w tej samej kategorii w edycji zorganizowanej w 2019 roku. Powieść Fluff została również nominowana w konkursie Książka Roku 2019 Polskiej Sekcji IBBY. Twórczość Osińskiej doceniono także poza światem literackim - na początku 2021 roku ogłoszono, że trwają prace nad filmową adaptacją Fanfika (Obarski, 2021); byłaby to zatem pierwsza polska ekranizacja książki młodzieżowej o postaciach LGBT.

$\mathrm{W}$ kolejnych latach pojawiły się dwie powieści młodzieżowe $\mathrm{z}$ wątkiem LGBT - w utworze Jak ziarnka piasku Joanny Jagiełło (2018) homoseksualny Łukasz jest przyjacielem głównej bohaterki, a narrator Hodowli Katarzyny Ryrych (2019) wspomina szkolne czasy z dawnym znajomym z klasy, który na końcu opowieści wyznaje mu prawdę o swojej orientacji. W toku opowiadanej przez nich historii okazuje się, że gejem był również najprawdopodobniej ich nieżyjący już kolega, znajdujący się niemal w centrum refleksji. Wydane zostały także dzieła prozatorskie całkowicie skupiające się na losach męskich postaci nieheteronormatywnych. Pierwsza to powieść Rado Boy Doroty Jaworskiej (2019). Choć książka promowana była jako nowy Fanfik i otrzymała rekomendację od Osińskiej, nie odniosła podobnego sukcesu. Główny bohater to maturzysta Kamil, zauroczony Wojciechem, znanym poetą. Homoseksualny jest też jeden z rówieśników Kamila. Następnymi takimi publikacjami są debiuty W mojej krwi Marka Szydlaka (2020) i Hurt/Comfort Weroniki Łodygi (2020). Powieść Szydlaka koncentruje się na historii szesnastoletniego Bartka, który poszukuje prawdziwej miłości i jednocześnie mierzy się z brakiem akceptacji ze strony najbliższych. Autorka Hurt/Comfort natomiast przedstawia powoli rozwijające się uczucie między dwoma maturzystami oraz problemy, z jakimi się zmagają na co dzień. W swojej drugiej książce - Angst with happy ending - Łodyga (2021) pozostaje przy tematyce LGBT. Jako że akcja powieści rozgrywa się w tym samym miejscu co w Hurt/Comfort, pojawiają się postacie znane już czytelnikom, ale pisarka skupia się przede wszystkim na nowej historii. Głównymi bohaterami są Aleks, który nie odczuwa pociągu fizycznego do żadnej osoby, wskutek czego nie myśli o nawiązaniu głębszej relacji, oraz jego homoseksualny przyjaciel Beniamin. Wraz z rozwojem akcji wychodzi na jaw, że również jeden ze znajomych Aleksa jest gejem, ale ukrywa swoją orientację i by nikt się nie domyślił prawdy, prześladuje rówieśników takich jak on sam. W polskich utworach młodzieżowych brakuje natomiast reprezentacji młodych osób biseksualnych - Fidowicz (2016, s. 60) odnalazła tylko jedną biseksualną nastolatkę, w książce Jedynaczka Andrzeja Klawittera (2002), według badaczki przedstawioną stereotypowo. W pierwszej powieści Łodygi przyjaciółka głównego bohatera jest biseksualna, jednak wątek romantyczny 
dotyczy tylko pierwszoplanowych postaci. Autorka zatem jedynie zwraca uwagę na obecność takiej osoby wśród młodzieży.

Mimo że stwierdzenie Wojciecha Śmiei (2010), iż polska literatura LGBT to „literatura, której nie ma”, zdaje się już nieprawdziwe, utworów prozatorskich dla młodego odbiorcy z nieheteroseksualnymi i transpłciowymi postaciami wciąż jest za mało. Być może dlatego nastoletni czytelnicy szukają opowiadań o tematyce LGBT w internecie, gdzie popularnością cieszą się pisane w języku polskim teksty fan fiction. Są to fanowskie utwory tworzone na podstawie książek, komiksów, filmów, seriali czy gier komputerowych i opowiadające najczęściej o dalszych losach wybranych bohaterów (Szpatowicz, 2021, s. 2). Wyodrębnia się m.in. dwie odmiany gatunkowe fan fiction związane $z$ tematyką LGBT - slashe oraz femslashe - obejmujące opowiadania, w których autorzy łączą w jednopłciowe pary postacie heteroseksualne bądź nieokreślone co do orientacji w oryginalnym tekście kultury (s. 4). Marta Szpatowicz zauważyła, że „narracje realizowane w ramach slashu pozwalają wyjść poza dominujący dyskurs" (s. 6), co może tłumaczyć, dlaczego nastolatki sięgają po te formy literackie. Sama Osińska w jednym z wywiadów zastanawiała się nad dużą popularnością fan fiction o homoseksualnych parach (Komender, 2017), a podczas rozmowy z Ulańską (2018b) dla Małego Formatu stwierdziła: „[...] dla mnie literatura LGBT w Polsce to są głównie fanfiki”. W sferze wirtualnej przeczytać można także oryginalne publikacje. Niektóre z nich zostały wydane nakładem własnym autorów ${ }^{20}$, np. Fałszywy wilkołak z serii Wilczy gryz oraz Cztery pory roku z cyklu Pierre i Raimundo Bartosza Brzezińskiego (kolejno 2016, 2019) czy Pierwszy września i Co z Oliwerem nie tak? pisarki tworzącej pod pseudonimem Dream Winchester (kolejno 2016, 2019). Często jednak powieści wydane w ten sposób nie docierają do szerokiego grona odbiorców, gdyż w przeciwieństwie do dzieł publikowanych przez tradycyjne wydawnictwa nie są dostępne w księgarniach ${ }^{21}$.

Popularność tematyki LGBT ${ }^{22}$ na stronach z opowiadaniami fan fiction świadczy o silnej potrzebie czytania przez nastoletnich odbiorców historii z udziałem bohaterów nieheteronormatywnych i transpłciowych. $\mathrm{Z}$ dokona-

20 Jest to samopublikowanie, tzw. self-publishing.

21 Przywołane przeze mnie dzieła można zakupić jedynie na stronie ich dystrybutora.

${ }^{22}$ Konrad Kuźma (2017, s. 228) opisał przeprowadzone wraz z zespołem badania, których celem było sprawdzenie, ile utworów fan fiction o uniwersum potterowskim opublikowanych na portalu https://www.fanfiction.net/ (pobrane 17 stycznia 2020) zawiera wątek homoseksualny dotyczący głównego bohatera, nieobecny w oryginalnej serii. Jak się okazało, spośród wszystkich opowiadań opublikowanych ówcześnie na wspomnianym portalu losy pary jednopłciowej opisywało 89,8\% tekstów w języku polskim oraz 55\% w angielskim. 
nego przeze mnie przeglądu można wyciągnąć wniosek, że liczba wydanych powieści o takiej tematyce nadal jest bardzo mała, a więc nie odpowiada na potrzeby czytelników i dlatego sięgają oni do internetu zamiast na półki księgarń czy bibliotek. Być może dzięki ponownemu zbiorowemu coming outowi, jakim było masowe wychodzenie z ukrycia za pośrednictwem mediów społecznościowych wskutek wydarzeń w Polsce w latach 2019-2020, w niedalekiej przyszłości liczba polskich utworów prozatorskich z nastoletnimi bohaterami LGBT wzrośnie, a orientacja nieheteroseksualna oraz transpłciowość powoli przestaną stanowić temat tabu.

\section{Zakończenie}

Mimo zmian w literaturze po 1989 roku, dopiero w ostatniej dekadzie polscy autorzy zaczęli zaznaczać obecność postaci nieheteronormatywnych i transpłciowych w powieściach dla nastoletnich czytelników, podczas gdy w USA już w drugiej połowie XX wieku młodzież nieheteroseksualna była reprezentowana w książkach przeznaczonych dla tej grupy wiekowej, choć nie zawsze bez reprodukowania stereotypów. Nie tłumaczono też na nasz język powieści amerykańskich kierowanych do młodych odbiorców - do tej pory większość tytułów nie doczekała się przekładu. Gdy w Stanach Zjednoczonych osoby LGBT zaczęły walczyć o swoje prawa, powoli stawały się obecne także w literaturze młodzieżowej ${ }^{23}$. W Polsce natomiast, mimo przeprowadzenia w 2003 roku pierwszych działań na rzecz widoczności społeczności LGBT, wciąż trudno mówić o szerokiej reprezentacji. Jest ona uboga w porównaniu do amerykańskiej, zwłaszcza $\mathrm{w}$ przedstawieniu nastoletnich osób biseksualnych oraz transpłciowych.

Jak zauważa Małgorzata Kita (2016), literatura LGBT może przekonać odbiorcę, że orientacja psychoseksualna czy tożsamość płciowa nie mają znaczenia, ponieważ czytelnik dostrzeże $\mathrm{w}$ dobrze wykreowanym bohaterze „człowieka: wątpiącego, szukającego swojej tożsamości, cierpiącego, solidarnego, kochającego" (s. 124) - czyli takiego samego jak inne postacie. Czytanie powieści lub opowiadań tego rodzaju może być też dla młodych osób jednym ze sposobów na pozyskiwanie informacji o tym, jak wygląda życie ludzi LGBT i ich związek z osobą tej samej płci (Abate, Kidd, 2011, s. 148). Poza tym Cart i Jenkins (2018, s. xiii) nadmieniają, że nie wszystkie nastolatki chcą się dzielić

23 Był to jednak bardzo powolny proces, gdyż w latach 70. pojawiło się zaledwie kilka książek, a do 1992 roku łącznie sześćdziesiąt, co stanowi bardzo małą liczbę, biorąc pod uwagę rozmiary amerykańskiego rynku wydawniczego. 
z innymi swoimi pierwszymi rozterkami związanymi z własną psychoseksualnością; niektóre bowiem wolą najpierw zapoznać się z nieheteronormatywną społecznością opisaną w książce. Zapewnienie fikcyjnych wzorów do naśladowania może więc pomóc dorastającym nastolatkom LGBT w lepszym zrozumieniu siebie, a tym samym w samoakceptacji. Istotne jest zatem, aby coraz częściej postacie nieheteronormatywne i transpłciowe pojawiały się w polskich książkach młodzieżowych, dzięki czemu młodsi czytelnicy będą mieli szansę zidentyfikować się z postaciami LGBT nie tylko z filmów i seriali dostępnych w naszym kraju ${ }^{24}$, lecz także z literatury. Adrianna Jackowiak (2014) określiła literaturę gejowską jako „narzędzie burzące społeczne tabu” (s. 171) w Polsce. Literatura młodzieżowa LGBT również może się stać takim narzędziem.

\section{Bibliografia}

Abate, M. A., Kidd, K. B. (2011). Over the rainbow: Queer children's and young adult literature. University of Michigan Press.

Aguirre-Sacasa, R. (prod.). (2017- ). Riverdale [serial telewizyjny]. CW.

Aguirre-Sacasa, R. (prod.). (2018-2020). Chilling adventures of Sabrina [serial telewizyjny]. Netflix.

Albertalli, B. (2016). Simon oraz inni homo sapiens (D. Olejnik, tłum.). Papierowy Księżyc. (wyd. oryg. 2015).

Albertalli, B. (2018). Leah gubi rytm (A. Brodzik, tłum.). We need YA.

Albertalli, B. (2019). Odwrotność nieodwzajemniona (D. Olejnik, M. Pianowska, tłum.). Papierowy Księżyc. (wyd. oryg. 2017).

Albertalli, B. (2020). Love, Creekwood. Balzer + Bray.

Albertalli, B., Silvera, A. (2019). A jeśli to my (A. Brodzik, tłum.). We need YA. (wyd. oryg. 2018).

Baluch, A. (2005). Książka jest światem. O literaturze dla dzieci małych oraz dla dzieci starszych i nastolatków. TAiWPN Universitas.

Basiuk, T. (2010). Coming out po polsku. W: J. Kochanowski, M. Abramowicz, R. Biedroń (red.), Queer Studies. Podręcznik kursu (s. 115-124). Kampania Przeciw Homofobii.

Beisert, M., Witkoś, M. (2018, 26 lipca). Niepewność wobec własnej tożsamości płciowej w okresie dorastania. Psychologia w Praktyce. Pobrane 17 stycznia 2020 z: https://psychologiawpraktyce.pl/artykul/niepewnosc-wobec-wlasnej-tozsamosciplciowej-w-okresie-dorastania.

24 M.in. Chilling Adventures of Sabrina (Aguirre-Sacasa, 2018-2020), Sex Education (Nunn, 2019- ) oraz Riverdale (Aguirre-Sacasa, 2017- ). 
Berger, E., Aptaker, I. (prod.) (2020). Love, Victor [serial telewizyjny]. Hulu.

Block, L. F. (1996). Girl Goddess \#9: Nine Stories. HarperCollins.

Boglar, K. (1991). Kolacja na Titanicu. Nasza Księgarnia.

Borowski, D. (2015). Między heteroseksualizmem a homoseksualizmem... O odkrywaniu orientacji seksualnej w powieści Koniec gry Anny Onichimowskiej. W: P. Tański, T. Dalasiński, A. Szwagrzyk (red.), Seksualność w najnowszej literaturze polskiej (s. 119-131). Inter-. Literatura-Krytyka-Kultura.

Berlanti, G. (reż.). (2018). Love, Simon [Twój Simon] [film]. $20^{\text {th }}$ Century Fox.

Brzeziński, B. (2016). Fałszywy Wilkołak. Bucketbook.

Brzeziński, B. (2019). Cztery pory roku. Bucketbook.

Callender, K. (2021). Felix Ever After. Na zawsze Felix (A. Brodzik, tłum.). We need YA. (wyd. oryg. 2020).

Całek, A., Olkusz, K., Korczak, A., Skowera, M. (2017). Ta dziwna instytucja zwana fantastyką młodzieżową. Creatio Fantastica, 56(1), 115-125.

Cart, M. (2010). Young adult literature: From romance to realism (wyd. 2). American Library Association.

Cart, M., Jenkins, C. A. (2006). The heart has its reasons: Young adult literature with gay/lesbian/queer content, 1969-2004. Scarecrow Press.

Cart, M., Jenkins, C. A. (2018). Representing the rainbow in young adult literature: $L G B T Q+$ content since 1969. Scarecrow Press.

Ciwoniuk, B. (2010). Musisz to komuś powiedzieć. Literatura.

Clare, C. (2009a). Miasto kości (A. Reszka, tłum.). Mag. (wyd. oryg. 2007).

Clare, C. (2009b). Miasto popiołów (A. Reszka, tłum.). Mag. (wyd. oryg. 2008).

Clare, C. (2010). Miasto szkła (A. Reszka, tłum.). Mag. (wyd. oryg. 2009).

Clare, C. (2011). Miasto upadłych aniołów (A. Reszka, tłum.). Mag.

Clare, C. (2012). Miasto zagubionych dusz (A. Reszka, tłum.). Mag.

Clare, C. (2014). Miasto niebiańskiego ognia (A. Reszka, tłum.). Mag.

Clare, C., Chu, W. (2020). Czerwone zwoje magii (M. Szalbierski, tłum.). We need YA. (wyd. oryg. 2019).

Czabanowska-Wróbel, A. (2013). [Ta dziwna] instytucja zwana literaturą dla dzieci. Historia literatury dla dzieci w perspektywie kulturowej. Teksty Drugie, 5, 13-24.

de Haan, L., Nijland, S. (2010). Król i król (S. Paszkiet, tłum.). AdPublik. (wyd. oryg. 2000).

Donovan, J. (1973). Dojdę tam - warto (J. Ględzka, tłum.). Iskry. (wyd. oryg. 1969).

Dragan, W. Ł., Iniewicz G. (red.). (2020). Orientacja seksualna. Źródła i konteksty. WN Scholar.

Edelfeldt, I. (1996). Jim w lustrze (Z. Erdmann, tłum.). Marcin Erdmann. (wyd. oryg. 1977). 
Fidowicz, A. (2016). Bohater nieheteronormatywny w powieści Nad czarna woda Haliny Górskiej. Zeszyty Naukowe Towarzystwa Doktorantów UJ. Nauki Humanistyczne, 15(4), 57-71.

Flood, A. (2011, 14 września). YA authors asked to 'straighten' gay characters. The Guardian. Pobrane 17 stycznia 2020 z: https://www.theguardian.com/books/2011/ sep/14/ya-authors-gay-characters.

Garden, N. (1982). Annie on my mind. Farrar, Straus \& Giroux.

Gibson, M. (reż.). (1993). The man without a face [Człowiek bez twarzy] [film]. Warner Bros.

Górska, H. (1931). Nad czarną wodą. Rój.

Green, J., Levithan, D. (2015). Will Grayson, Will Grayson (M. Białoń-Chalecka, tłum.). Bukowy Las. (wyd. oryg. 2010).

Gromadzka, B. (2018). Szkoła - dom - okolica. Wartościowanie przestrzeni w literaturze dla młodzieży. Polonistyka. Innowacje, 7, 59-70. https://doi.org/10.14746/ pi.2018.7.5.

Guy, R. (1976). Ruby. Viking Press.

Hinton, S. E. (1967). The outsiders. Viking Press.

Holland, I. (1972). The man without a face. Lippincott.

Howlett, G. (2015, 24 lutego). Why are so many adults reading YA and teen fiction?. The Guardian. Pobrane 17 stycznia 2020 z: https://www.theguardian.com/childrens-books-site/2015/feb/24/why-are-so-many-adults-reading-ya-teen-fiction.

Iniewicz, G., Grabski, B., Mijas, M. (red.). (2012). Wprowadzenie do psychologii LGB. Continuo.

Jabłoński, W. (1988). Gorące uczynki. Wydawnictwo Łódzkie.

Jackowiak, A. (2014). Poetyka (nie)wyrażalnego pożądania, czyli zarys historii powieści gejowskiej w Polsce na tle socjologiczno-kulturowym. Studia Europaea Gnesnensia, 10, 169-194. https://doi.org/10.14746/seg.2014.10.9.

Jagiełło, J. (2018). Jak ziarnka piasku. Nasza Księgarnia.

Jaworska, D. (2019). Rado Boy. Wydawnictwo Krytyki Politycznej.

John Green Books. (b.d.). Will Grayson, Will Grayson. Pobrane 10 lipca 2020 z: https:// www.johngreenbooks.com/will-grayson-will-grayson.

Kerr, M. E. (1977). I'll love you when you're more like me. HarperCollins.

Kerr, M. E. (1994). Deliver us from Evie. Harper \& Row.

Kerr, M. E. (1997). "Hello," I lied. HarperCollins.

Kita, M. (2016). Coming out w polskiej przestrzeni dyskursywnej. Wydawnictwo UŚ.

Klawitter, A. (2002). Jedynaczka. Telbit.

Komender, D. (2017, 13 stycznia). Dlaczego polskie nastolatki zaczytują się w historiach o gejowskich związkach?. Vice. Pobrane 17 stycznia 2020 z: https://www.vice. 
com/pl/article/3dd8vw/dlaczego-polskie-nastolatki-zaczytuja-sie-w-historiach-ogejowskich-zwiazkach.

Krzemiński, I. (2010). Społeczna historia homoseksualności. Ruch wyzwolenia (szkic do problematyki). W: J. Kochanowski, M. Abramowicz, R. Biedroń (red.), Queer Studies. Podręcznik kursu (s. 27-57). Kampania Przeciw Homofobii.

Kujawska-Kot, A. (2018). Od impulsu fotografii do narracji tożsamościowej. Funkcje fotografii bohaterów transpłciowych w ich życiu. Rynek - Społeczeństwo - Kultura, 27(1), 91-99.

Kujawska-Kot, A. (2020). Bohater transseksualny w objęciach binarnego kodu płci. O parajęzykowych i werbalnych formach komunikowania. Przeglad Socjologiczny, 69(1), 55-80. https://doi.org/10.26485/PS/2020/69.1/3.

Kuźma, K. (2017). Nasze potrzeby - dlaczego tworzymy utwory bazujące na miłości męsko-męskiej. W: P. Szymczyk, E. Chodźko (red.), Motyw miłości w wybranych tekstach literackich i innych dziedzinach kultury (s. 228-240). WN Tygiel.

Kwaśniewski, T. (2013). Jedno oko na Maroko. Czarna Owieczka.

Lang, B. (2018, 9 marca). Love, Simon stars say gay teen romance will save lives. Variety. Pobrane 17 stycznia $2020 \mathrm{z}$ : https://variety.com/2018/scene/vpage/love-simonpremiere-gay-teen-romantic-comedy-1202722636/.

Levithan, D. (2003). Boy meets boy. Alfred A. Knopf.

Levithan, D. (2013). Two boys kissing. Alfred A. Knopf.

Lindenbaum, P. (2012). Zlatanka i ukochany wujek (K. Skalska, tłum.). Zakamarki. (wyd. oryg. 2006).

Łodyga, W. (2020). Hurt/comfort. Wydawnictwo Kobiece.

Łodyga, W. (2021). Angst with happy ending. Wydawnictwo Kobiece.

Malec, B. (2017). Ludzie są jak „fan fiction”. Na przykładzie Fanfika Natalii Osińskiej. Artes Humanae, 2, 175-187. http://doi.org/10.17951/arte.2017.2.175.

Mikołajczak, M. (2019). Parę słów o polskiej prozie lesbijskiej po 2007 roku na przykładzie powieści Ewy Schilling, Zofii Staniszewskiej i Anny Arendt. Młoda Humanistyka, 14(1). Pobrane 17 stycznia 2020 z: http://www.humanistyka.com/index. $\mathrm{php} / \mathrm{MH} / \mathrm{article} / \mathrm{view} / 235$.

Mochocka, A. (2017). Two perspectives on the performative social body: Teenage make-up routines in Fanfik and the Jeżycjada cycle. Miscellanea Posttotalitariana Wratislaviensia, 2, 87-115.

Musiał, G. (1989). W ptaszarni. Czytelnik.

Nunn, L. (prod.). (2019- ). Sex education [serial telewizyjny]. Netflix.

NCAC Staff. (1996, 1 maja). Books in trouble 2. National Coalition Against Censorship. Pobrane 17 stycznia $2020 \mathrm{z}$ : https://ncac.org/update/books-in-trouble-2/.

Obarski, P. (2021, 3 lutego). Trwają prace nad ekranizacją powieści Natalii Osińskiej. Granice.pl. Pobrane 7 marca 2020 z: https://www.granice.pl/news/fanfik-ekranizacja-powiesci-natalii-osinskiej/11558. 
Obuchowska, I. (1996). Drogi dorastania. Psychologia rozwojowa okresu dorastania dla rodziców i wychowawców. WSiP.

Onichimowska, A. (2012). Koniec gry. Znak.

Osińska, N. (2016). Fanfik. Wydawnictwo Krytyki Politycznej.

Osińska, N. (2017). Slash. Agora.

Osińska, N. (2019). Fluff. Agora.

Out.com Editors. (2016, 8 marca). Who are the 2016 Lambda Literary Awards finalists?. Out. Pobrane 17 stycznia 2020 z: https://www.out.com/art-books/2016/3/08/lambdaliterary-awards-finalists-revealed-carrie-brownstein-hasan-namir-truman.

Packer, V. (1952). Spring fire. Gold Medal Books.

Parnell, P., Richardson, J. (2009). Z Tango jest nas troje (K. Remin, tłum.). Adpublik. (wyd. oryg. 2005).

Pawłowska, M., Szamałek, J. (2015). Kim jest ślimak Sam?. Wydawnictwo Krytyki Politycznej.

Peters, J. A. (2004). Luna. Little, Brown \& Company.

Peterson, V. (2018, 16 grudnia). Young adult and new adult book markets. The Balance Careers. Pobrane 17 stycznia 2020 z: https://www.thebalancecareers.com/theyoung-adult-book-market-2799954.

Rees, D. (1985). In the tent. Alyson. (wyd. oryg. 1979).

Rejter, A. (2014). „Mój chłopak, facet z plakatu, ciota darkroomówka...”. Wizerunek mężczyzny w gejowskiej literaturze popularnej. Język Artystyczny, 15, 65-87.

Reszczyńska-Urban, K. (2019). Inicjacje bohaterów nieheteronormatywnych w Fanfiku i Slashu Natalii Osińskiej. Dzieciństwo. Literatura i Kultura, 1(1), 221-235. https://doi.org/10.32798/dlk.31.

Rogulska, P. (2006). Rzeczywistość alternatywna? Lubiewo Michała Witkowskiego. InterAlia, 1. Pobrane 17 stycznia $2020 \mathrm{z}$ : https://interalia.queerstudies.pl/issues/1_2006/12_rzeczywistosc_alternatywna_lubiewo_michala_witkowskiego.htm.

Rowell, R. (2016). Nie poddawaj się (M. Hesko-Kołodzińska, tłum.). HarperCollins Polska. (wyd. oryg. 2015).

Rowell, R. (2019). Zbłąkany syn (D. Stadnik, tłum.). HarperCollins Polska.

Rusinek, M. i in. (2021). Wszystkie kolory świata. Agora.

Ryan, S. (2001). Empress of the world. Penguin Books.

Ryrych, K. (2019). Hodowla. Adamada.

Scoppettone, S. (1974). Trying hard to hear you. Harper \& Row.

Silvera, A. (2018). Raczej szczęśliwy niż nie (S. Chojnacka, tłum.). Wydawnictwo Poznańskie. (wyd. oryg. 2015).

Silvera, A. (2018). Zostawiłeś mi tylko przeszłość (A. Brodzik, tłum.). We need YA. (wyd. oryg. 2017).

Silvera, A. (2019). Nasz ostatni dzień (A. Brodzik, tłum.). We need YA. (wyd. oryg. 2017). 
Silvera, A. (2021). Syn nieskończoności (A. Brodzik, tłum.). We need YA. (wyd. oryg. 2020). Sobolczyk, P. (2015). Przekroczyć społeczną barierę „deprawacji nieletniego”. Bohater homoseksualny w literaturze dla dzieci i młodzieży. W: P. Sobolczyk (red.), Queerowe subwersje. Polska literatura homotekstualna i zmiana społeczna (s. 472495). Wydawnictwo IBL PAN.

Sterling, I. (2020). Te wiedźmy nie płoną. (A. Kalus, tłum.). We need YA. (wyd. oryg. 2019).

Sterling, I. (2021). Ten sabat nie upadnie. (A. Kalus, tłum.). We need YA. (wyd. oryg. 2020).

Struzik, J. (red.). (2012). Niewidoczne (dla) społeczności. Sytuacja społeczna lesbijek $i$ kobiet biseksualnych mieszkajacych na terenach wiejskich $i$ w małych miastach $w$ Polsce. Raport $z$ badań. Fundacja Przestrzeń Kobiet.

Sullivan, M. W. (1976). What's this about Pete? Thomas Nelson.

Szpatowicz, M. (2021). Cierpienie i pocieszenie w slashu. Rana. Literatura - Doświadczenie - Tożsamość, 1(3), 1-15. https://doi.org/10.31261/Rana.2021.3.09.

Szydlak, M. (2020). W mojej krwi. Novae Res.

Śmieja, W. (2010). Literatura, której nie ma. Szkice o polskiej „literaturze homoseksualnej". TAiWPN Universitas.

Tomasik, K. (2012). Gejerel. Mniejszości seksualne w PRL-u. Wydawnictwo Krytyki Politycznej.

Ulańska, Z. (2018a). Miłość silniejsza niż płeć? Nowe oblicza polskiej literatury LGBT na przykładzie twórczości Natalii Osińskiej i Marcina Szczygielskiego. W: P. Szymczyk, E. Chodźko (red.), Motyw miłości w wybranych tekstach literackich i innych dziedzinach kultury (s. 274-288). WN Tygiel.

Ulańska, Z. (2018b, maj). Od empatii do akceptacji. Rozmowa z Natalią Osińską. Mały Format. Pobrane 17 stycznia 2020 z: http://malyformat.com/2018/05/od-empatiido-akceptacji-rozmowa-z-natalia-osinska.

van Dijk, L. (1995). Damned strong love: The true story of Willi G. and Stefan K. (E. D. Crawford, tłum.). Henry Holt. (wyd. oryg. 1991).

van Dijk, L. (2017). Cholernie mocna miłość. Prawdziwa historia Stefana K. i Williego G. (A. Chmielecka, F. Fierek, tłum.). Korporacja Ha!art. (wyd. oryg. 1991).

Warkocki, B. (2014). Trzy fale emancypacji homoseksualnej w Polsce. Porównania, 15, 121-132.

Waters, M. (2009, 13 czerwca). How Stonewall liberated young adult literature. Electric Literature. Pobrane 17 stycznia 2020 z: https:/electricliterature.com/how-stonewall-liberated-young-adult-literature.

Winchester, D. (2016). Pierwszy września. Bucketbook.

Winchester, D. (2019). Co z Oliwerem nie tak?. Bucketbook.

Witkowski, M. (2004). Lubiewo. Korporacja Ha!art.

Wittlinger, E. (2007). Parrotfish. Simon \& Schuster. 